\title{
FEMALE STUDENTS' PARTICIPATION IN MATHEMATICS EDUCATION AT THE UNIVERSITY LEVEL IN GHANA
}

\author{
Christopher Yarkwah \\ Department of Mathematics and ICT Education \\ University of Cape Coast \\ Cape Coast, Ghana \\ cyarkwah@ucc.edu.gh
}

\begin{abstract}
For more than three decades now, a great body of research studies have been conducted to address the issue of gender disparities in mathematics education across the globe as a result of the minimal participation of females in mathematics education in higher levels of education. The primary purpose of this study, however, was to investigate female students' participation in mathematics education at the university level. It considered 99 female students' studying mathematics education from the University of Cape Coast and the University of Education, Winneba. The study used descriptive survey design to analyse both qualitative and quantitative data gathered from respondents. The study revealed among other things that the trend of enrolment of female students' in mathematics education is on the decline. Also, the study revealed that enjoyment derived from studying mathematics education, career opportunities in mathematics education, desire to study mathematics education, interest in mathematics education, were some of the reasons why female students participate in mathematics education. The assertion that mathematics is a male domain subject was not a perception of female mathematics education students who participated in this study. Conclusions, implications and recommendations are further discussed in the work.
\end{abstract}

KEYWORDS: female students, participation, perception, mathematics education, university level

\section{INTRODUCTION AND STATEMENT OF THE PROBLEM}

Universally, mathematics is virtually dominant in almost every aspect of man's life such that in our world of science and technology, it has played an important role and continues to be relevant to other various fields of study. It cannot be overemphasized that the study of mathematics disciplines the mind, and equips one to develop critical thinking ability and reasoning. Mathematics occupies a privileged position in the Ghanaian school curriculum. In that, it is not only because of the ability to cope with it that improves one's chances of social advancement, but because it is a core subject which every learner must at least learn up to the Senior High School level (Fletcher, 2009). As the saying goes that, "behind every successful man, there is a woman". This presupposes that women are the ideal supporters of men to become successful. This brings to the fore that the involvement of women in mathematics education in Ghana and 
Vol.8, Issue 4, pp.30-45, April 2020

Published by ECRTD- UK

Print ISSN: ISSN 2054-6351

Online ISSN: ISSN 2054-636X

the world at large is very crucial in changing the teaching and learning of mathematics to a large extent. Over the years, participation of female students in mathematics in higher levels of education has attracted massive attention by various researchers across the globe. Collective efforts of nations to address the situation of gender inequality in education and occupation has been taken by many researchers as far back in the 1940s in global and at national levels. The United Nations established the Commission on the Status of Women (UN-CSW) in 1946 which was aimed at gender equality and advancement of women in member states.

Although several international organisations such as the United Organisation advocates gender equity in all spheres of life, Griffith (2010) asserted that gender disparities in mathematics starts from the infant stages of one's life, however, it deteriorates as one rise through college. El Yacoubi (2015) postulated that even though equity in education exists in most developed countries, female enrolment in mathematics is relatively low. Freeman (2004) asserts that, all across the globe, females attained two-thirds representing almost $67 \%$ of all degrees awarded at the undergraduate level, however, a few of these degrees are attained in science and technology. In a nutshell, Jacobs and Simpkins (2005) revealed that, of all the women that enrol and are able to finish a terminal degree, only $1 \%$ attain $\mathrm{PhD}$ degrees in science, technology, engineering, and mathematics (STEM) related fields. The story was not different ten years later, in 2015, women earned $42 \%$ of the Doctoral degrees in Physical, Life, Computer, Earth and Social Sciences, Psychology and Engineering, nonetheless females received only $25 \%$ of the $\mathrm{PhD}$ degrees in mathematics and computer sciences in 2015 (National Science Foundation, 2016).

Several studies (see for example, Ma, \& Kishor, 1997; Casey, Nuttal \& Pezaris, 2001; Odogwu, \& Lawal, 2018) have been conducted on the participation of females in mathematics in Africa and some other parts of the world. In these studies, women's ability to do mathematics, lack of confidence in females, and the perception that mathematics is a male domain subject are the attributing factors of low participation rate in mathematics. The low confidence of girls to participate in mathematics at higher level does not only affect it, but in the field of mathematics education as well. Odogwu, and Lawal (2018) investigated into representation of female mathematics teachers, their interests and career progression in mathematics education in Nigeria. Using a sample of 187 mathematics teachers which consisted of 82 females and 105 males, the findings revealed that $68.4 \%$ of the female mathematics teachers possess a degree in mathematics education related courses. It was further revealed that most female mathematics teachers representing $51.7 \%$ of the mathematics teacher population were teaching at the Junior Secondary School level, while at the Senior Secondary School level, females represent $35.2 \%$ of mathematics teachers. It is evident from their results that female mathematics teachers are more dominant at the basic levels of education compared to the second cycle institutions. This could be as a result that several female teachers fail to partake in higher degrees in mathematics education. 
Vol.8, Issue 4, pp.30-45, April 2020

Published by ECRTD- UK

Print ISSN: ISSN 2054-6351

Online ISSN: ISSN 2054-636X

The key question that several researchers have resorted to finding answers to is the reasons behind the level of female students' participation in mathematics education at the higher levels of the educational system. A qualitative study by Gudyanga, Mandizvidza and Gudyanga (2016) revealed that female students hold the perception that mathematics is a difficult subject, a male domain subject and also irrelevant to their career ambitions. Also, it was discovered that cultural stereotypes also barred female students to partake in mathematics education at the higher level. A research conducted by Kaino (1996) which sought to find out the sources of influence of women to the study of mathematics at the university level in Swaziland revealed that teachers were less likely to encourage girls to participate in mathematics and science even with girls' schools where they performed better and could be confident to further study the subject, it was not seen. While girls performed equally well in mathematics with boys, studies conducted by Lafortune (1989) showed that girls still had some negative attitudes towards the course due to their greater anxiety towards mathematics learning and it was an attribute to their low participation at the university level. A study by Fletcher (2009) which sought to find out the extent to which the enrolment of females onto mathematics courses reflected an increase in female enrolment proportions in Ghanaian universities. His study was designed to identify the sources of influence of women in the study of mathematics, the careers of women in mathematics, and the perceptions of female undergraduate mathematics students revealed the following: women opted to become teachers at the end of the programme and only few women considered engineering and technology, apart from women's self-confidence and high ability in mathematics, fathers influenced the women most to study mathematics at the university level, women were less likely to be influenced by male or female role models in mathematics, the dryness of the subject was also an attribute of the low participation rate of females in mathematics at the university level in Ghana. In consonance with the aforementioned study, Acheampong (2014) investigated into disparity of gender participation of females in STEM related fields in higher education in Ghana. It was exposed that, even though Ghana had a population of about twenty-four million of which females form fifty-one percent of the entire population (Ghana Statistical Service, 2012), there is still a minority of females participating in higher education in the fields of STEM.

Also, Mandina, Mashingaidze and Mafuta (2013) discovered numerous factors that are accountable for the low participation of females in mathematics education in their study on increasing female participation in advanced level mathematics. Some of the factors included; absence of self-confidence, negative stereotypes about mathematics abilities of females, perceived difficulty of mathematics, anxiety, negative teacher attitudes, cultural belief that mathematics is a male domain subject and ignorance of career opportunities available in pursuing mathematics. Irrespective of the emergence of several research studies across the globe, much of these works focus on STEM fields and not particularly mathematics on its own. A few of such studies have been conducted in Ghana. In relation to this background, it is imperative to explore female students' participation in mathematics education at the University level in Ghana. The 
purpose of the study is to investigate female students' participation trend in mathematics education at the university level in Ghana over a period of ten years from 2007-2016. The study further explored some major reasons influencing female participation in mathematics education at the University level.

In a study, Yarkwah, Arthur and Donkor (2020) looked at readiness of senior high school students readiness to pursue advanced mathematics at the university level. Data for the study was obtained from 317 senior high school students from three public schools in the Cape Coast Metropolis in the Central Region of Ghana. Primarily, the study was composed of 317 final year elective mathematics students made up of 196 females and 121 males. Data for the study was collected through the use of questionnaires. The researchers used the descriptive survey as the main design and data collected was analyzed using simple graphs, percentages, descriptive and inferential statistics. It was revealed generally, in the study that there was an appreciable difference between Single-Sex Female students and their counterparts in the Single-Sex Male school's readiness to pursue advanced mathematics at the university level. In their study it was made known that these two schools differ in mean readiness scores by approximately $0.241(\mathrm{p}=.006<.05)$ which was observed as a very large effect size. Based on their findings it was concluded that Single-Sex Female school students showed more readiness to pursue advanced mathematics at the university level as compared to their counterparts in the Single-sex male school. Their study also indicated that there was no statistically significant difference between students in the Single-sex female school and their counterparts in Mixed Schools regarding their readiness to pursue advanced mathematics at the university level with mean difference of $0.08360, \mathrm{p}=0.573>0.05$. Their results presuppose that female students are more willing and ready to pursue advanced mathematics than their male counterparts at the highest level of education and as a result must be encouraged.

\section{Research Questions}

To ascertain the primary purpose of the study, the following research questions were explored:

1. What is the trend of enrolment of female students in mathematics education in the two public universities?

2. What accounts for female students' participation in mathematics education at the university level?

3. What factors motivate female students to participate in mathematics education at the university level?

4. How do female students perceive mathematics education as a programme?

5. What career prospects are available for female mathematics education students?

\section{Design and Instrumentation}

The study resorted to using the descriptive-survey as the main design. The study used descriptive survey design because it helps to reveal issues concerning the study, and it is useful when the 
variables under consideration are about thoughts, opinions and reasons. Universally, survey is believed to be relatively easy to administer, cost effective, time effective, and can cover multiple variables. The instrument for this study was questionnaire. In conducting a survey study, Mugenda and Mugenda (2003) proposed that the ideal instruments to employ are questionnaires which are also widely used in educational research to obtain data. This is because it is very effective way for collecting data on the attitudes and opinions of several respondents and also they help secure functional information about practices and conditions (Yin, 2003). The questionnaire had thirty-one (31) items containing demographic information about respondents and closed ended questions of which respondents were made to their responses to each item respectively. The questionnaire consists of two parts, Parts I and II. Part I is based on demographic information of the respondents whereas Part II is structured in five-point Likert scale pattern and has been sub-divided into four sections based on each research question.

\section{Selection of participants}

The target population of this study was female students` participating in mathematics education in two Ghanaian public universities. However, the accessible population was female undergraduate mathematics education students at the University of Education, Winneba and the University of Cape Coast during the second semester of the 2016/2017 academic year.

Table 1: Female students` participation in mathematics education at the University of Cape Coast and the University of Education, Winneba for the 2016/2017 academic year.

\begin{tabular}{lrrrrrr}
\hline Institution & Level & 100 & 200 & 300 & 400 & Total \\
\hline University of Cape Coast & 18 & 13 & 27 & 22 & 80 \\
$\begin{array}{l}\text { University of } \\
\text { Winneba }\end{array}$ & Education, & 16 & 19 & 13 & 13 & 61 \\
\hline Total & 34 & 32 & 40 & 35 & 141 \\
\hline
\end{tabular}

In an attempt to have a sizable and manageable proportion of the respondents, researchers agreed to use $70 \%$ of participants which represents 99 out of a total number of 141 students. To ensure total representativeness of the population, purposeful sampling procedure was used to select universities. Thus, they are mainly the two public universities offering mathematics education in Ghana which can be used to draw inferences on the population under consideration taken into consideration the ten-year range considered in this study. The selected sample was distributed across all levels of students in their current studies based on the number of students at each level and institution using Quota-Sampling technique; $70 \%$ representing 57 out of a total number of 80 in the University of Cape Coast and $70 \%$ representing 42 out of a total number of 61 at the 
Vol.8, Issue 4, pp.30-45, April 2020

Published by ECRTD- UK

Print ISSN: ISSN 2054-6351

Online ISSN: ISSN 2054-636X

University of Education, Winneba. Based on the Quota-sampling technique, the following were the respective sample size of each level in the two public universities under consideration. Level 100(13), level 200(09), level 300(19) and level 400(16) at the University of Cape Coast and level 100 (11), level 200(13), level 300(09) and level 400(09) at the University of Education, Winneba. The sample size was selected because it represents at least more than an average of the total number of female students' participating in mathematics education for the year ranges 20132017.

\section{Validity and Reliability of Instrument}

The instrument was subject to intense scrutiny to confirm its validity and reliability. Some mathematics educators from the University of Cape Coast were inquired to analyse the instrument for content validity. The items on the questionnaire were reduced from 42 items to 31 items. The Cronbach Alpha coefficient was determined to evaluate the internal consistency of the items. The four subsections (A, B, C, D) of the instruments had reliability coefficients of $0.79,0.71,0.72,0.77$ respectively. These coefficients represent a high reliability as emphasized by Ellis (2013) that many authors adhere to the rule that reliability coefficient of group research should be at least 0.70 .

\section{Data Collection Procedure}

In order to ensure smooth administration of the questionnaire, an introductory letter was collected by the researchers from the Department of Mathematics and I.C.T Education, University of Cape Coast and sent to participating schools to seek permission before data collection was done. Also, to ensure that the instrument used are returned by respondents, the administration and retrieval of the instruments were carried out by the researchers themselves during and after normal lecture hours, and visits to the other participating schools by the researchers was also executed. A total of 99 questionnaires were distributed in the selected institutions. This was done by researchers moving from lecture theatre to another to collect data. This made it possible for the researchers to be able to retrieve all the 99 questionnaires they issued out to the respondents to ensure a $100 \%$ return. Respondents were required to use 45 minutes in answering the questionnaire.

\section{Data analysis and Discussion}

In order to analyse the data to be able to investigate the female students" participation in mathematics education at the university level, mean and standard deviation of each item was used to compare the mean of a five-point Likert scale with reference to frequencies and percentages. In tackling the question on the enrolment trend, researchers used the enrolment of female students ' in mathematics education for 10 years (2007-2016) to draw a frequency polygon to illustrate the trend. A bar chart was drawn to show the regional distribution of female students in mathematics education from 2013-2017 in Ghana. Researchers used frequency polygon because it is the best chart to illustrate the trend of enrolment of female students' participation in mathematics education. Bar chart was used because the variable under consideration with 
Vol.8, Issue 4, pp.30-45, April 2020

Published by ECRTD- UK

Print ISSN: ISSN 2054-6351

Online ISSN: ISSN 2054-636X

regards to the regional distribution is discrete and it was to compare the various regions. Descriptive statistics was used to analyse the Likert scale variables summarized into mean and standard deviation with reference to frequencies and percentages for onward interpretation. To determine whether respondents were in support of the items listed in the tables with respect to the research question, the mean of each item was used to compare with the mean of a five-point Likert scale. The average mean of the five-point Likert scale in this case was 3.0. As a result, any mean above the threshold of 3.0 confirms respondents support, equivalent to 3.0 is indecisive and below 3.0 confirms respondents not in support.

\section{RESULTS AND DISCUSSION}

Research question one: What is the trend of enrolment of female students` in mathematics education in the two public universities?

To analyse this research question data base about enrolment of females into the mathematics education program in the two selected Universities were obtained ranging from 2007 to 2016. The results are presented in the Table 1.

Table 2: Enrolment of female students in University of Cape Coast and University of Education Winneba from 2007-2016

\begin{tabular}{lccc}
\hline Academic Year & University of Cape Coast & $\begin{array}{c}\text { University of Education, } \\
\text { Winneba }\end{array}$ & Total \\
\hline $2007 / 2008$ & 16 & 43 & 59 \\
$2008 / 2009$ & 09 & 52 & 61 \\
$2009 / 2010$ & 09 & 45 & 67 \\
$2010 / 2011$ & 11 & 56 & 33 \\
$2011 / 2012$ & 08 & 25 & 31 \\
$2012 / 2013$ & 16 & 15 & 35 \\
$2013 / 2014$ & 22 & 13 & 40 \\
$2014 / 2015$ & 27 & 13 & 32 \\
$2015 / 2016$ & 13 & 19 & 34 \\
$2016 / 2017$ & 18 & 16 & \\
\hline Total & 149 & & 446 \\
\hline
\end{tabular}


The data was further illustrated using frequency polygon to clearly show the trend of female participation in mathematics education at the University level.

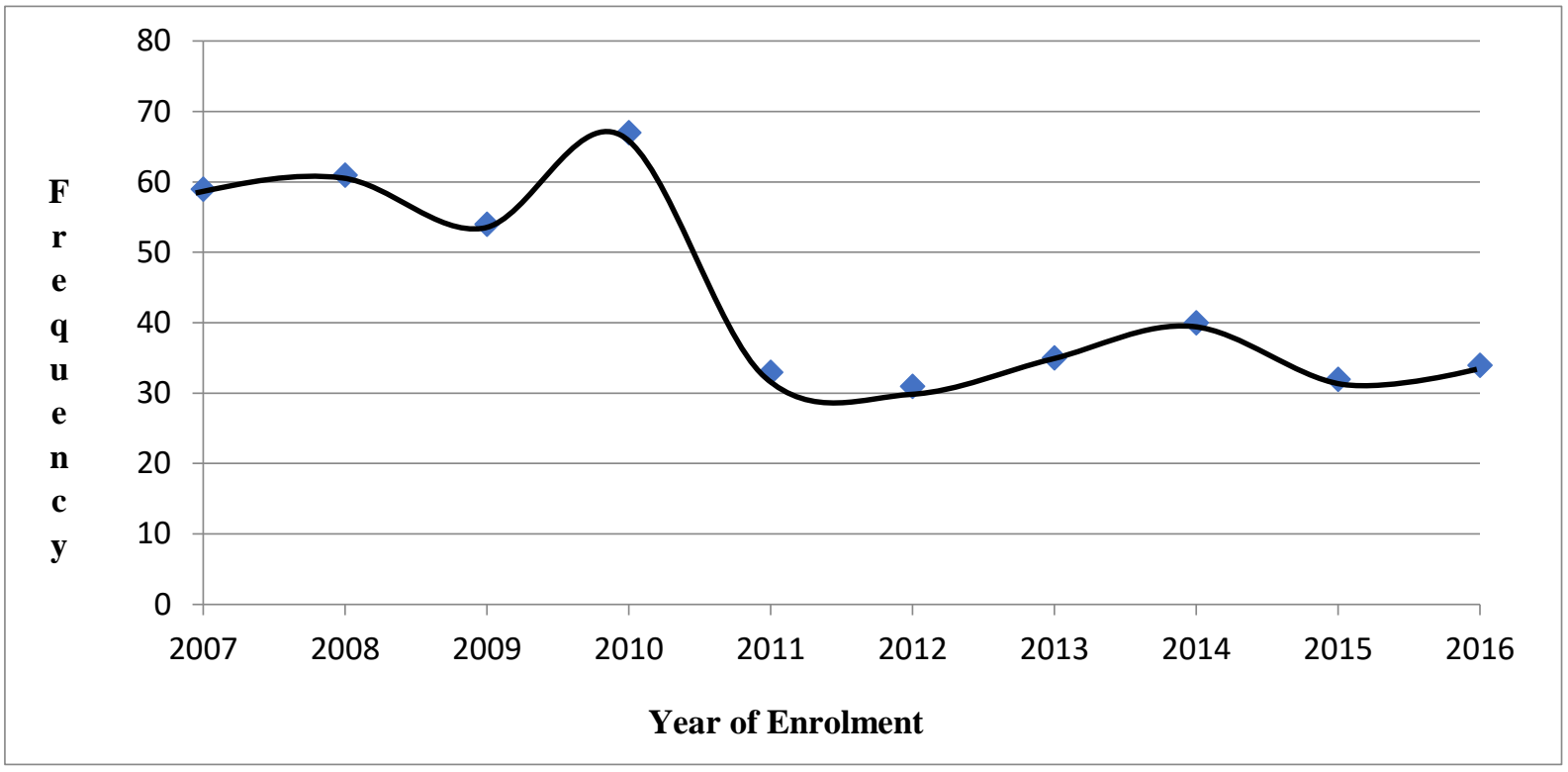

Figure 1: The Trend of Female students' enrolment in mathematics education from 20072016

Figure 1 and Table 2 represents the trend of enrolment of female students in mathematics education. It was based on the sample selected from institutions under consideration. With reference to Figure 1, it can be seen that the participation of female students' in mathematics education were higher from 2007-2010, it became unstable after 2010 onwards as the curve increases in some years and decreases in other years. Considering the last 5 years, enrolments of female students' in mathematics education from 2012 to 2016 were lower as compared to the enrolment of female students' in mathematics education from 2007 to 2011. This is a clear indication that in recent years, female students' participation in mathematics education has been on a decline. The finding is in consonance with that of (Jacobs \& Simpkins 2005; Grifith, 2010; El Yacoubi, 2015) who discovered that enrolment of females in mathematics and females' participation in mathematics education at higher levels of education is relatively low. The finding is also in contrast to the finding by Yarkwah, Arthur and Donkor (2020) which asserted that students from Single-Sex female schools are more willing and ready to pursue advanced mathematics at the university level than their male counters from the Single-Sex Male schools. The general finding presupposes that at the highest level of education only few females are involved in mathematics education and mathematics related programmes. This low female participation rate could also stem from the fact that most females do not select mathematics education and mathematics related programmes as a programme of interest. It could also stem 
from the fact the most females do not meet the threshold of admission let alone gain admission into the programme in question.

\section{Research question two: What accounts for female students`participation in mathematics education at the university level?}

To answer the second research question, responses provided by respondents were analysed using means and standard deviations. The results are indicated in Table 3.

Table 3: Mean and standard Deviation scores of Factors that account for female students` Participation in Mathematics Education

\begin{tabular}{llcc}
\hline $\begin{array}{l}\text { Item } \\
\text { No. }\end{array}$ & \multicolumn{1}{c}{ Statement } & Mean & $\begin{array}{c}\text { Standard } \\
\text { deviation }\end{array}$ \\
\hline 1 & Enjoyment in mathematics education & 4.2 & 0.8 \\
2 & Greater opportunities in mathematics education & 4.4 & 0.6 \\
3 & I was good at mathematics at the SHS & 4.4 & 0.6 \\
4 & Mathematics education interests me & 4.1 & 0.9 \\
5 & My personal capabilities & 4.1 & 0.9 \\
6 & I had the desire to change how mathematics is & 4.3 & 0.7 \\
& taught as a subject. & & 0.6 \\
7 & I want to offer help to others & 4.4 & \\
\hline
\end{tabular}

Table 3 considered some of the factors that accounted for female students' participation in mathematics education. Participants were in support of all the items as factors that accounted for their participation in mathematics education. This is clarified by comparing their respective means with the average mean of 3.0. It is seen in Table 3 that; the mean of each item is greater than the average mean. For instance, item 2, 3, 6 and 7 had means of 4.4, 4.4, 4.3 and 4.4 which is more than the mean of 3.0 respectively. It can be inferred from the findings that female students agreed to all the statements as possible factors that influenced their participation in mathematics education at the University level. Therefore, respondents who took part in this study asserted that they enrolled on the mathematics education programme because: they enjoy studying mathematics education, it opens greater job opportunities for students, desire to change how mathematics is taught as a subject. Also, previous mathematical experience and personal capabilities asserted in a study by Fletcher (2009) was strongly confirmed as a reason for female students' participation in mathematics education. This means that female students enrol on the mathematics education programme mainly because of the seven reasons discussed.

To support this assertion made by the respondents, some of them who were interviewed had this to say:

"What has accounted for me pursuing mathematics education is the fact that I see myself working in other sectors of the economy than in the education sector" 
British Journal of Education

Vol.8, Issue 4, pp.30-45, April 2020

Published by ECRTD- UK

Print ISSN: ISSN 2054-6351

Online ISSN: ISSN 2054-636X

"My desire to pursue this programme stem from the fact that a lot of people see mathematics as a difficult subject and I want to change the way it is taught and people's perception about the subject"

These statements by some of the respondents go to support why females pursue mathematics education at the university level.

\section{Research Question three: What factors motivate female students' to participate in mathematics education at the university level?}

The third research question which also sought to find out the factors that motivate students was analysed using means and standard deviations. The results are showcased in the Table 4 below.

Table 4: Mean and Standard Deviation Scores of Factors that Motivate Female students to Participate in Mathematics Education

\begin{tabular}{|c|c|c|c|}
\hline $\begin{array}{l}\text { Item } \\
\text { No. }\end{array}$ & Statement & Mean & $\begin{array}{l}\text { Standard } \\
\text { Deviation }\end{array}$ \\
\hline 8 & I believe I will receive an excellent CGPA & 4.1 & 0.9 \\
\hline 9 & Interest level in mathematics & 4.1 & 0.9 \\
\hline 10 & Prospects of the programme & 4.2 & 0.8 \\
\hline 11 & $\begin{array}{l}\text { Confidence level in dealing with } \\
\text { mathematical task. }\end{array}$ & 4.4 & 0.6 \\
\hline 12 & The career goals of the programme & 4.2 & 0.8 \\
\hline 13 & Parents/Family influence & 4.0 & 1.0 \\
\hline 14 & Friends & 3.7 & 1.3 \\
\hline
\end{tabular}

Table 4 concentrated on the issues or factors that motivate female students in pursuing mathematics education as a programme. Even though, all the issues or factors in Table 4 were the motivating factors of female mathematics education students as they all recorded means greater than 3.0. Generally, students had very high inclination towards what motivates them to pursue mathematics education at the university level. A cursory look at Table 4 indicates that all items recorded mean scores above 3.0 indicating that respondents who participated in the study were highly motivated to pursue mathematics education. This shows that students' selfconfidence about their abilities in mathematics and career goals and many others in mathematics education play significant role in motivating them to continually have interest in their quest to study mathematics education at the higher level. This finding confirms the sources of influence of women in the study of mathematics aforementioned by Fletcher (2009). 
British Journal of Education

Vol.8, Issue 4, pp.30-45, April 2020

Published by ECRTD- UK

Print ISSN: ISSN 2054-6351

Online ISSN: ISSN 2054-636X

\section{Research Question four: How do female students perceive mathematics education as a programme?}

This research question aimed at identifying the perceptions female students hold about their mathematics education program at the University level. Means and standard deviations were employed to make inferences on the results presented in the Table 5 below.

Table 5: Mean and Standard Deviation scores of Perceptions of Female Mathematics Education Students

\begin{tabular}{llcc}
\hline $\begin{array}{c}\text { Item } \\
\text { No. }\end{array}$ & Statement & Mean & $\begin{array}{c}\text { Standard } \\
\text { Deviation }\end{array}$ \\
\hline 15 & Mathematics is a masculine subject & 1.8 & 3.2 \\
$16 \quad \begin{array}{l}\text { I perceive there are greater salary opportunities in } \\
\text { pursuing mathematics education }\end{array}$ & 3.3 & 1.7 \\
$17 \quad \begin{array}{l}\text { I perceive there is security in Mathematics } \\
\text { education professions }\end{array}$ & 4.0 & 1.0 \\
$18 \quad \begin{array}{l}\text { Mathematics education is perceived to be a } \\
\text { challenging programme. }\end{array}$ & 3.9 & 1.1 \\
$19 \quad \begin{array}{l}\text { I perceive the product of mathematics education } \\
\text { end up teaching }\end{array}$ & 3.3 & 1.7 \\
$\begin{array}{l}\text { I perceive I will be able to obtain my desired class } \\
\text { in the course }\end{array}$ & 3.2 & 1.8 \\
$\begin{array}{l}\text { I perceive Mathematics education involve mere } \\
\text { manipulations of figures }\end{array}$ & 2.8 & 2.2 \\
\hline
\end{tabular}

A critical look at Table 5 reveals that the female students in the selected Universities perceived that there is job security in mathematics education as a profession $(\mathrm{M}=4.0, \mathrm{SD}=1.0)$. Analysis of data revealed that generally female mathematics education students have positive perception towards the programme. This presupposes that the students see the programme to be attractive and with much prospects. However, item by item analysis on this subscale indicated that some of the items revealed a negative perception. For instance, Item 21 which sought to find out whether they (female mathematics education students) perceive mathematics education to involve mere manipulation of figures revealed a negative perception. This could mean that female students perceive that mathematics education goes beyond mere manipulation of figures. Also, the respondents strongly refuted the assertion that "mathematics is a masculine subject" $(\mathrm{M}=1.8, \mathrm{SD}=3.2)$. The belief that mathematics is a masculine subject had a mean score below the perception subscale mean score, which implies that the belief that mathematics is a masculine subject was not a perception of female mathematics education students. This finding defies the finding of Bosswell (1985) which asserted that "mathematics is a masculine subject". Therefore, female students have the following perception about mathematics education: there is greater salary opportunities in mathematics education, there is job security in mathematics education, mathematics is a challenging course and the products of mathematics education end up teaching. 
The findings are not in agreement with that of Gudyanga et al. (2016). A qualitative study by Gudyanga et al. (2016) revealed that female students perceive mathematics as a difficult subject, a male domain subject and also irrelevant to their career ambitions.

\section{Research Question five: What career prospects are available for female mathematics education students?}

The last research question was used to ascertain the career prospects available for female mathematics education students. Data assembled on this research question was analysed using means and standard deviations. The results are presented in the Table 6 below.

Table 6: Mean and Standard Deviation scores of Career Choices of Female Mathematics Education Students

\begin{tabular}{|c|c|c|c|}
\hline $\begin{array}{l}\text { Item } \\
\text { No. }\end{array}$ & Statement & Mean & $\begin{array}{l}\text { Standard } \\
\text { Deviation }\end{array}$ \\
\hline 22 & $\begin{array}{l}\text { The course will help me gain the skills that I need } \\
\text { to impart into society }\end{array}$ & 4.3 & 0.7 \\
\hline 23 & Mathematics education has many career options & 4.2 & 0.8 \\
\hline 24 & $\begin{array}{l}\text { Mathematics education will help me gain the skills } \\
\text { that I need to apply in other fields }\end{array}$ & 4.3 & 0.7 \\
\hline 25 & $\begin{array}{l}\text { There is job security in being Mathematics } \\
\text { educator. }\end{array}$ & 4.2 & 0.8 \\
\hline 26 & $\begin{array}{l}\text { Mathematics education will help me achieve my } \\
\text { career goals. }\end{array}$ & 4.2 & 0.8 \\
\hline 27 & Teaching mathematics is lucrative & 4.1 & 0.9 \\
\hline 28 & $\begin{array}{l}\text { My SHS teachers serve as role models to me in this } \\
\text { course. }\end{array}$ & 4.2 & 0.8 \\
\hline
\end{tabular}

Table 6 was based on finding out the career choices of female students' in mathematics education. The issues raised in Table 6 were all supported by participants as the career choices they considered in mathematics education as they recorded means greater than average mean of 3.0. Item by item analysis revealed that item 22 and 24 which represent mathematics education helping students to gain the skills they will need to impart into society as well as mathematics education helping students to gain the skills they need to apply in other fields respectively were most considered by participants in their pursuance of mathematics education. This is a clear indication that career opportunity available to students is one of the key reasons why female students will consider participating in mathematics education at the University level. This discovery corroborates with that of Odogwu and Lawal (2018) who identified that interests of female students and their career progression in mathematics education were key reasons for their participation in mathematics education at the higher level. 
To ascertain their awareness of major career choices available to them as female students pursuing mathematics education, respondents listed the following as the career choices at their disposal or associated with mathematics education as a programme:

\section{Teaching \\ 2. Banking \\ 3. Statistician \\ 4. Data Analyst \\ 5. Data collection support services \\ 6. Insurance Personnel \\ 7. Project Analyst \\ 8. Working in industry in general}

The above career choices were the dominant career mentioned by $80.8 \%$ (80 out of 99) of the respondents. A cursory look at the career choices indicates that female students who participated in this study are well informed about various career choices available to them after completion of the programme. This also presupposes that female students undertaking mathematics education programme are very much aware that teaching as a profession is not the only career choice available to them after going through the programme. They however admitted that they are very much aware that teaching as a profession is the core mandate of the programme hence the first career choice.

\section{CONCLUSIONS AND IMPLICATIONS TO TEACHING AND LEARNING MATHEMATICS}

The trend of female students' enrolment in mathematics education, especially in the last five years is on the decline. This means that the admission of female students in mathematics education is falling yearly and this calls for attention. The belief that mathematics is a masculine subject was not a perception of female mathematics education students. This presupposes that most females are beginning to realise the need for them to go into mathematics education and mathematics related programmes in that they believe this would propel them to higher heights. This also means that females no longer see mathematics as a difficult programme and for that matter are willing to go into the programme. Generally, female students gave reasons for participating in mathematics education to be the following: their capabilities, their desire to study mathematics education, greater job opportunities in mathematics education, the motivation to offer help to others, and the enjoyment they derive from mathematics education. Furthermore, findings showed that career choice was one of the main influencers of female students' participation in mathematics education. They however, listed eight major career choices as those they see to be associated with mathematics education programme. 


\section{Recommendation}

Based on the findings that female students' participation in mathematics education in the last five years of the years under consideration is on the decline, the government should provide grants for female students participating in mathematics education. In addition, tertiary institutions running such programmes should faction out a special admission cut-off points for female applicants who decide to enrol unto mathematics education.

Another consideration is the fact that stakeholders in mathematics education should improvise means of encouraging female students to participate in mathematics education at the university level. To this end, policy makers and implementers should take keen interest in creating the needed career opportunity awareness to female students who participate in mathematics education.

Furthermore, since career choices was a genuine factor for female students' participation revealed in the study, government should provide more career opportunities for female students' participating in mathematics education?

It is also recommended that tertiary institutions that run mathematics education programmes should endeavour as much as possible to develop courses that seeks to address career opportunities in mathematics education and mathematics related programmes for students' perusal especially for the sake of female students.

\section{Suggestions for Further Research}

In order to continue building upon the literature on female students' participation in mathematics education at the university level, it is recommended that a comprehensive study be conducted on enrolment trend in mathematics education, mathematics related programmes as well as career opportunities of female students across the country's tertiary institutions. This to a large extent would help know the general enrolment trend in mathematics in the country. Further, a study should be conducted to look at ways of improving female student's enrolment in mathematics education.

\section{References}

Acheampong, A. B. (2014). Inequality of Gender Participation of Females in STEM Disciplines in Higher Education A case study of KNUST: Ghana (Master's thesis). University of Oslo.

Casey, M. B., Nuttall, R. L., \& Pezaris, E. (2001). Spatial-mechanical reasoning skills versus mathematics self-confidence as mediators of gender differences on mathematics subtests using cross-national gender-based items. Journal for research in mathematics education, 28-57. 
British Journal of Education

Vol.8, Issue 4, pp.30-45, April 2020

Published by ECRTD- UK

Print ISSN: ISSN 2054-6351

Online ISSN: ISSN 2054-636X

El Yacoubi, N. (2015). Gender and Mathematics education in Africa. In Cho, S. J. (ed) Gender and Mathematics education revisited. The Proceedings of the 12th International Congress on Mathematical Education. Springer Open.

Ellis, J. L. (2013). A standard for test reliability in group research. Behavior research methods, 45(1), 16-24.

Fletcher, J. (2009). Participation of women in mathematics at the university level. Adults Learning Mathematics, 3, 1-13.

Freeman, C. E. (2004). Trends in educational equity of girls \& women: 2004. Education Statistics Quarterly, 6(4), 357-66.

Ghana Statistical Service (2010). Population and Census Ghana. Accra: Sakoa Press. pp.16.

Griffith, A. L. (2010). "Persistence of women and minorities in STEM field majors: Is it the school that matters?" Economics of Education Review. 29(6), 911-922.

Gudyanga, A., Mandizvidza, V., \& Gudyanga, E. (2016). Participation of rural Zimbabwean female students in mathematics: The influence of perception. Cogent Education, 3(1), $1-14$.

Jacobs, J. E. \& Simpkins, S. D. (2005). Twenty-five years of research on gender and ethnic differences in math and science career choices: what have we learned? New Directions for Child and Adolescent Development, 110, 85-94.

Kaino, L. M. (1997). The analysis of gender differences in attitudes towards the study of maths among secondary and high school students in Swaziland. Unpublished Research Report.

Lafortune, L. (1989). Attitudes, Differences at Enseignement Des Mathematiques. Quelle Différences, 151-158.

Ma, X., \& Kishor, N. (1997). Attitude toward self, social factors, and achievement in mathematics: A meta-analytic review. Educational Psychology Review, 9(2), 89-120.

Mandina, S., Mashingaidze, S. S., \& Mafuta, J. (2013). Increasing Female Participation in Advanced Level Mathematics: A Perspective from Students and Teachers in Zimbabwe. African Educational Research Journal, 1(3), 183-190.

Mugenda, M. O. \& Mugenda A. (2003), Research Methods: Qualitative and Quantitative Approaches, Nairobi: African Centre for Technology Studies.

National Science Foundation, (2016). National Centre for Science and Engineering Statistics. Doctorate Recipients from U.S. Universities: 2015. Special Report NSF 17-306. Arlington, VA.

Odogwu, H. N. \& Lawal, R. F. (2018). Women Representation, Interest and Career Progression in Mathematics Education: An Analysis of Teachers at the Secondary School Level. Akoka Journal of Pure and Applied Science Education, 16 (1), 91 - 105.

William, Y. V., James, W. M. \& Colleen, A. R. (2014). Report on the 2012-2013 New Doctoral Recipients. Notices of the American Mathematical Society, 61(8) 874-884. http://www.ams.org/profession/data/annual-survey/2013Survey-NewDoctoratesReport.pdf 
British Journal of Education

Vol.8, Issue 4, pp.30-45, April 2020

Published by ECRTD- UK

Print ISSN: ISSN 2054-6351

Online ISSN: ISSN 2054-636X

Yarkwah, C., Arthur, B. E., \& Donkor, M. (2020). Senior high school elective mathematics students' readiness to pursue advanced mathematics at the university level. International Journal of Education, Learning and Development, 8(3), 28-51.

Yin, R. K. (2003). Case study research: design and methods (ed.). California: Thousand Oaks. 